\title{
Dialectological description of the Russian language functioning in the Baidar Valley of Greater Sevastopol
}

\author{
Natalia Antonenko ${ }^{1, *}$, and Tatiana Teplova ${ }^{1}$ \\ ${ }^{1}$ Sevastopol Branch of Lomonosov Moscow State University, 7, Geroev Sevastopolia, 299001, Sevastopol, Russia
}

\begin{abstract}
The paper discusses the main stages of investigation into the dialectological situation in the South of Russia, with special attention being given to the studies of territories close to the Republic of Crimea. This paper presents findings from a field study of the Russian language functioning in an isolated area. We investigate speech of the people living in Greater Sevastopol to identify peculiar features in phonetics, word building, morphology and syntax. Our respondents are both natives and migrants from various regions. The regiolect of Sevastopol is analysed in terms of dialect bases and their correlation, time of migration. Our results show positive relationship between the respondents linguistic and biographic background. The speech of the respondents exhibits a high degree of similarity with the Russian literary language, and demonstrates features of the closely related Ukrainian language. The influence of Ukrainian is more pronounced at the phonetic level and less evident at the lexical level.
\end{abstract}

\section{Introduction}

Changes in the language require ongoing and accurate registration since "it is difficult for the collector of dialectal material and a dictionary compiler to identify an item which stands behind the lexeme reported by the subject and a semantic description follows the context immediately which can lead to serious mistakes difficult to find in a consolidate dictionary and to correct" [1].

In 1972 N. A. Meshchersky qualified a more accurate classification of Russian accents as one of the tasks of dialectology. Such classification should depict dialects in all areas where Russian is spoken [2]. Present-day political and economic processes intensified stratification and changes of dialect idioms. It makes the social trend in research of Russian accents currently important.

Traditional accents are modifying, losing some archaic features and acquiring new ones. In contemporary science these transformed dialects are referred to as regiolects.

According to the opinion of the authors who study features of linguistic mapping in describing language functioning in a bounded locality, "describing the making of new sociolects and regiolects, their shaping together with dialect recomposition of the Russian language is an important task in modern dialectology" [3]. Such description is directly related with the fact that regional usage has always been different in the Russian speaking territory. But it is obvious for those who find themselves in an unusual language environment. And those who don't migrate much are not aware of the non-normativity of their patterns of usage [4].

E. V. Brysina, R. I. Kudryashova and V. I. Suprun in their article "Present-day dialects lexicography: issues and developmental trends" consider heterogeneity of dialects and divergent ways of regional dialects genesis as one of the main issues. They prove that areas where Russians were original inhabitants are dialectally homogenious, while the areas where Russians settled later are characterised by heterogeneous accents [5].

The situation in the area around Sevastopol and in Greater Sevastopol is rather complex. The works on dialectology do not discuss the features of accents of later settlers of this and some other areas. The region is not depicted on the dialect area maps of the year 1965 . According to the dialects map of the Russian language in Europe constructed by N. N. Durnovo, N. N. Sokolov and D. N. Ushakov in 1914 and elaborated by N. N. Durnovo in 1927 the Crimea was classified as the area of Little Russian accents as well as the territories of Lvov, Kharkov and Ekaterinoslav located in different parts of Ukraine [6]. Such distribution does not take into consideration many factors which we will discuss later. However, the Crimean territory is marked as territory where the Russian-speaking population makes up less than $50 \%$ of the general quantity population makes up less than $50 \%$ of the general quantity of inhabitants.

The complexity of systematization and characterization are associated with the difficulties of analyzing and classifying heterogeneous and mixed dialects. It is noteworthy that part of the territories allocated by the Moscow dialectological commission (MDC) were not included in the maps of the Dialectological Atlas of the Russian language. Among the territories not included in the Atlas and closest to the Crimea and Sevastopol is the area within the Southern Great Russian division represented by the southern part of

\footnotetext{
*Corresponding author: straga98@mail.ru
} 
the southern group of dialects in the middle and lower Don and Stavropol [7].

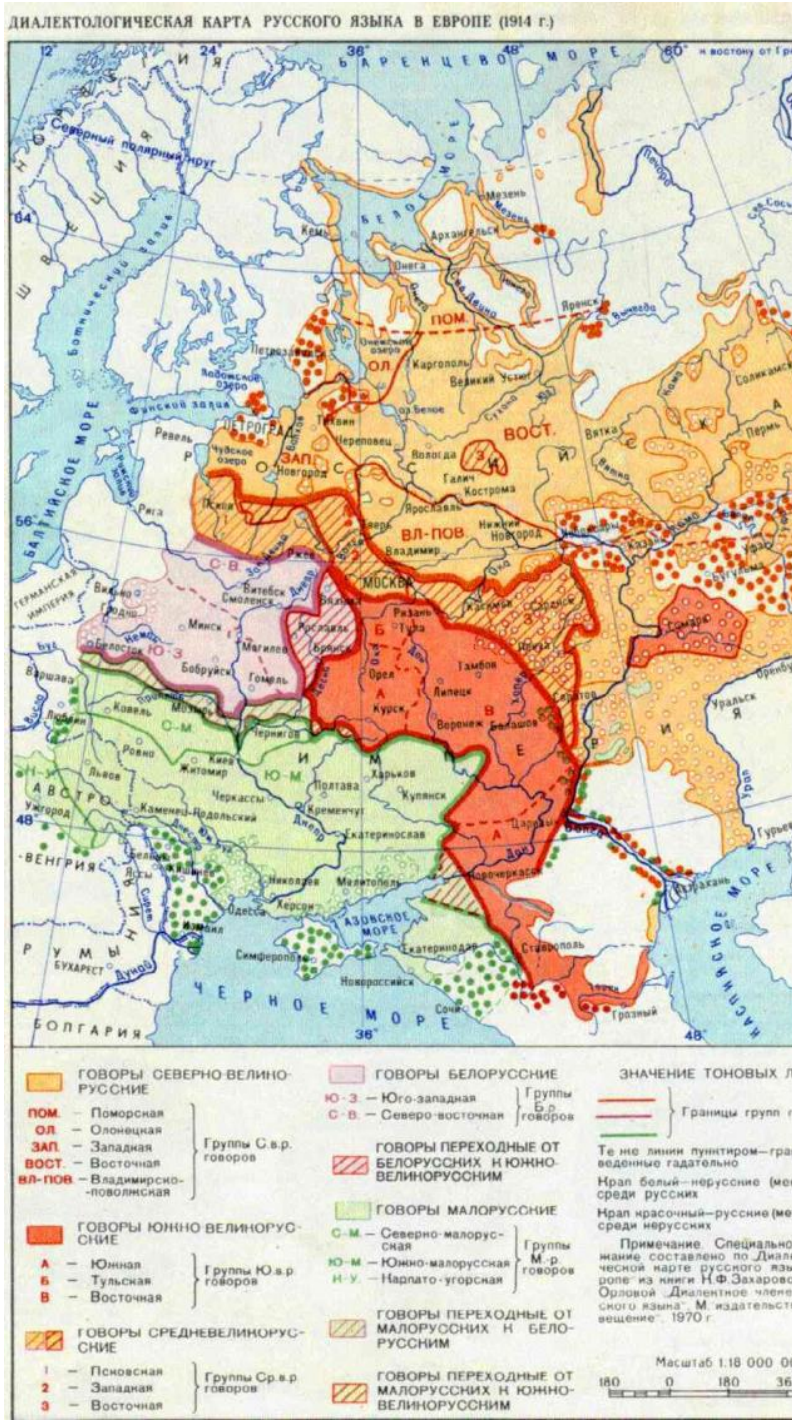

Fig. 1. The dialects map of the Russian language in Europe constructed in 1914. The Crimea is classified as the area of Little Russian accents (the green field).

The 3rd edition of the "Russian Dialectology" textbook, edited by L. L. Kasatkin, updates the dialectal division of the Russian language and describes the territories of the late formation of the Southern division (the Don complexes [8], but the language situation in the modern Republic of Crimea and Sevastopol still remains unlit. It should be noted that the variability of the Russian language in the Crimea is recognized as a pressing issue of dialectology [9], a group of dialects is included) and their language

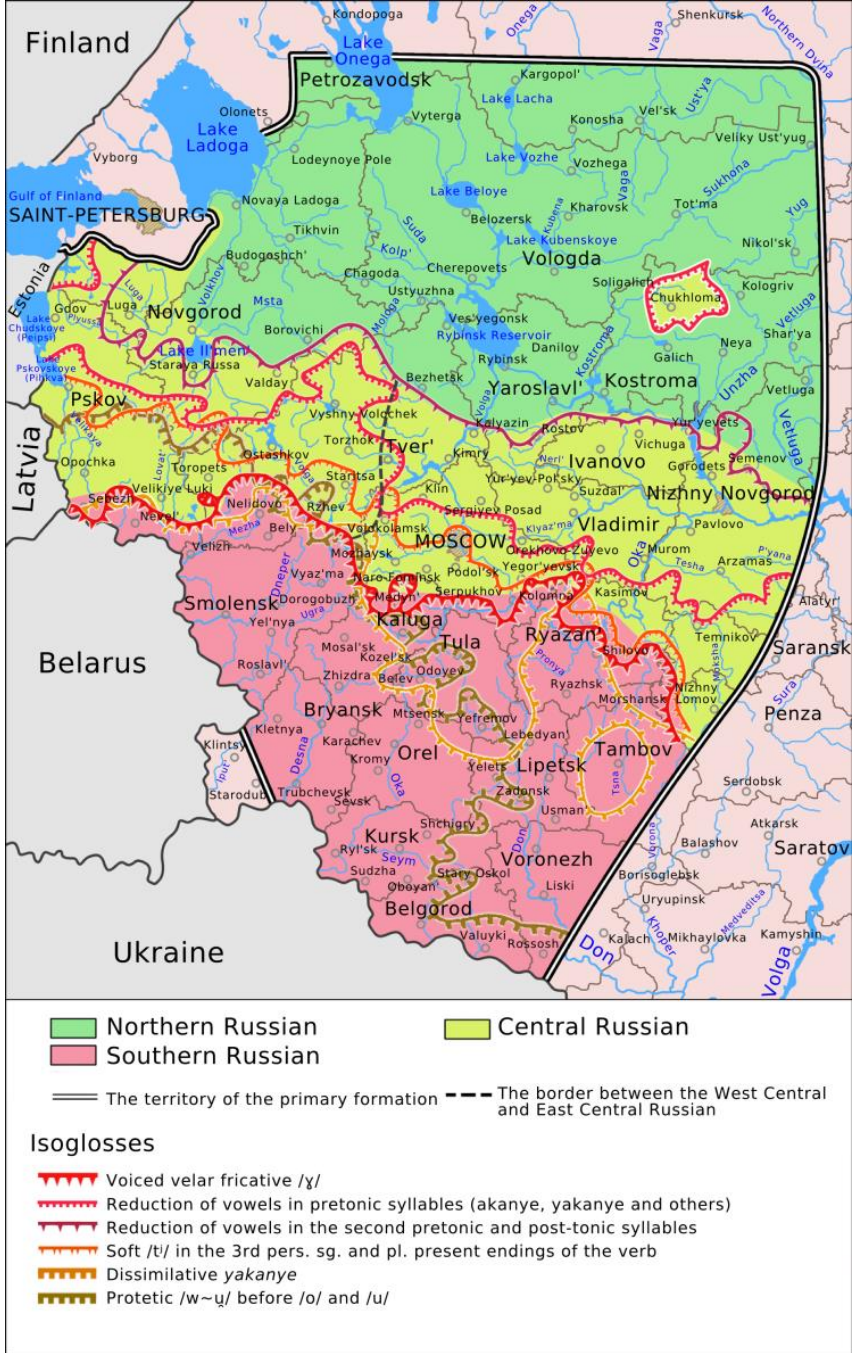

Fig. 2. The map of the Dialectological Atlas of the Russian language. The Crimea and Sevastopol are not included.

The complexity of the systemic description of the Russian language functioning within the region (the Russian language regiolect) becomes apparent if we try to characterize the regiolect using the system proposed by L. I. Barannikova [10]. From the point of view of the nature of the dialect basis of the accent, the Sevastopol regiolect is rarer than the bi-dialect or polydialect type, which is connected with the historical conditions of the formation of the population. Modern residents of Greater Sevastopol are natives or descendants of immigrants from Kursk, Voronezh, Bryansk, Tver regions of the modern Russian Federation and Bessarabia, Vinnitsa, Transcarpathia, Donetsk regions of Ukraine. In the past few decades, speakers of an unrelated Crimean Tatar language have been added to them, making the language environment even more heterogeneous.

Such heterogeneous situation complicates the determination of the ratio of dialectal bases and allows talking about two types of dialects: dialectal diversity of accents (significant differences at the level of different groups of dialects and language divisions, complicated by a foreign language environment) and / or a foreign language environment (interaction of Russian accents of 
immigrants with both closely related and unrelated languages).

Late resettlement time allows us to talk about primary migratory accents and the differentiation of the nature of the relationship with the native accents. At the same time, the task of determining the native accent itself does not lose its importance.

The Russian language in Sevastopol was the subject of an independent study within the framework of monitoring the Russian language functioning in Sevastopol. The study was held on the initiative of the Sevastopol City Council in 2007. The results of this monitoring will be used as one of the basis of the research. The Russian language in Crimea was the subject of a study within the framework of the Global Russian studies project (georusistika) conducted by prof. A. N. Rudyakov (Simferopol) on the basis of a hypothesis about the existence of a special Ukrainian version of the Russian language. At the same time, the available data are rather fragmented and mosaic in nature, dealing mainly with lexical innovations. These data do not adequately characterize active processes in the regiolect, and the regiolect has not been the subject of a special research with the use of special methods.

As noted in [11], a systematic description of a regiolect functioning requires consideration of extralinguistic factors that form the national, cultural and political identity of the population with various cultural settings, ethnicity and religious denominations. From this point of view, the Sevastopol region (Greater Sevastopol) is close to a reference region and the issues discussed above are typical for it.

Since the end of the Great Patriotic War various political processes have taken place on the territory of Sevastopol (liberation of the peninsula, transfer of the region from the RSFSR to the Ukrainian SSR, existence within the post-Soviet Ukraine, reunification with Russia). Each of these processes is accompanied by mass migrations of the population. A logical consequence is a change in the system of education connected with the teaching of Russian, Ukrainian and Crimean Tatar languages in schools..

\section{Materials and methods}

We have developed a questionnaire for conducting dialectological and sociolinguistic studies in Greater Sevastopol and Crimea.

Given the specifics of the study, the interviewers did not inform the respondents about the real objectives of the survey. In order to avoid deliberate distortion of speech in the direction of the codified norm, the respondent was informed of the expedition's local history purposes. This made it possible to obtain audio recordings reflecting the present language situation.

According to Yu. L. Sit'ko, the grammar and phonetics of the urban vernacular in the Crimea and Sevastopol correlate with koine as the main means of everyday communication in various communicative spheres in regular social contacts [12]. This statement is applicable to Greater Sevastopol as well. Our findings include phonetic, morphological, syntactic and lexical aspects of speech. At the same time, linguistic and biographical information correlate positively.

\section{Results}

We identify three groups of respondents: immigrants from the RSFSR, immigrants from the Ukrainian SSR and natives of the region. In most cases, Russian was mentioned as the native language, but there were cases of difficulty in answering this question ("I don't know which one" and "I normally speak"). Lyubov V, born in 1939, a native of Vinnytsia region, in whose speech the features of the Ukrainian literary language are more pronounced than those of Russian, replied: [men'i ne zdajets'a sho ja po ukrajins'komu rozgavarivayu] (I don't think that I speak Ukrainian). Maria Ts., of the same age and from the same region as Lyubov V., characterized her spoken language as follows: [a vzhe v'in u mene tak polovynu rusky/polovynu ukrains'ky// ja fse pon'imaju po rus 'ky/ po ukrajins'ky $i$ koje shto po n'imetsky pon'imaju] (I speak half Russian, half Ukrainian. I understand everything in Russian, in Ukrainian, and I understand something in German).

Migrants retain language features which are typical for their region. So, the speech of the representatives of the first group is distinguished by a complete akanie (reduced pronunciation of unstressed [o] as [a]), which is typical of the Russian literary language. Respondents from the second group demonstrate partial okanie (retention of unstressed [o]), which can be explained by their origin and a long stay in a heterogeneous environment.

The situation in the group of the natives of the region is rather unclear. Lyubov S. was born in 1947 in a family of immigrants from the Voronezh region, received a secondary education. Her speech reveals akanie ([karova]) and okanie simultaneously ([ovosh':i]), the convergence of the sounds [i] and [y], as, for example, in the word [pryjehal'i]. However, this feature is neither permanent in the speech of the respondent nor ubiquitous in the surveyed territory.

All three groups of the research participants pronounce unvoiced labio-dental sounds [f] and [ $\mathrm{f}$ ] for phonemes phonemes $<\mathrm{v}>$ and $<_{\mathrm{V}}{ }^{\prime}>$. The bilabial allophones $[\mathrm{w}],\left[\mathrm{w}^{\prime}\right]$ and $[\check{y}]$ were demonstrated by respondents who migrated from Transcarpathia and Bessarabia. This feature is not present in the speech of immigrants from other regions of the Ukrainian SSR. Voiced back-lingual consonants are mainly explosives and often are presented as $[\gamma]$ and $\left[\gamma^{\prime}\right]$. This is typical for both settlers and the natives. Even more frequent is the unvoicing of the back-lingual sounds [g] and [g '] both as $[\mathrm{k}] /\left[\mathrm{k}^{\prime}\right]$, and $[\mathrm{kh}] /\left[\mathrm{kh}^{\prime}\right]$.

We have observed cases of dissimilation of fricative consonants ([obshch'ezhyt'ije], [konkhv'eta]), but these cases are not regular. Instead of [j] after the consonant before the vowel, there can be a zero of sound: [sv'in'a], [tr'et'em].

Some respondents demonstrate diaeresis of unstressed vowels. This mainly refers to post-tonic syllables, especially to the final open syllable. And the center of the 
syllable is usually transferred to a consonant sound: [vazhat(o)j], [ét(o) sámaje].

Word-building models absolutely coincide with the models of the Russian literary language. Modern trends of word formation (the formation of nouns with the suffix "izatsia", the prefixes of the size-valued semantics ("giper", "super-" ..), the prefixes of the opposition "de-", "anti-" and others) are not found in the respondents speech.

The morphology and syntax are generally consistent with the codified norm, although a number of fluctuations are noted. One of the deviations from the norm is a change in the gender of the noun. The feminine nouns are replaced by the neutral and vice versa: [tri déreva/ $n$ 'i odná ne vrodila] (three trees and none of them produced fruits) and [pach'imuta mn'e uch'enija n'eshla] (For some reason, I did not succeed in school). Extremely common in the speech of all three groups of respondents are the word forms of the demonstrative pronoun "tot", "vot", "tut": "toi", "ot/oto", "otut" respectively. The normative ending [y $\mathrm{i}]$ is replaced with the ending [a]: pochorona nachalis' and mater'a (plural of the lexeme mat'). The ending [if] may replace [of]: [staryk'if], [muzhyk'if], [pravnuk'if].

The plural form of the instrumental case of names can get the ending [amy] for nouns and pronouns: [d'itkamy], [vamy], [kustamy].

Forms of the nominative case singular of masculine adjectives and pronouns are pronounced with the stressed ending [yj]: [khvatkyj], [takyj].

In the genitive case of masculine and neuter genders in adjectives and impersonal pronouns, the ending is formed with the consonant $[\mathrm{v}]:$ polno $[v] \mathrm{o}$, interesno $[v] \mathrm{o}$, tako[v]o.

The reflexive postfix after vowels can take the form "sya": uchilasya, vypuskalasya, obshchalisya.

The preposition "iz" can be replaced with the preposition "s": vypuskalasya s sadika, lozhkami s odnogo kazana, ona s goroda priezhaet.

Some variations in the syntax system are explained by the interference of closely related languages. This is most clearly manifested in the interaction of prepositions and nouns and is accompanied by a fluctuation of the morphological system. Examples of such changes are the statements [robili na tabaku] and [uchilisya v khutor'i].

The lexicon of respondents coincides with the lexicon of the Russian language. According to Yu. L. Sit'ko, this explains the absence of very bright features in the wordformation system of Sevastopol, and the existing new words completely fit into the word-formation system of the Russian literary language [12]. Deviations from the norm may refer to the so-called "individual" lexicon.

\section{Discussion}

Our paper presents result of the field study of the Russian language functioning in the isolated area. It was the first linguistic research that was held on the Baidar Valley site. The results of our survey are confirmed in [11]. Relatively low indicator of confirming can be attributed to the low state of studied question knowledge. Our research allows us to expand the boundaries of the Russian language dialectological description on the territories, which were not investigated before. Minor flaws of investigation can be explained by human factors and lor technical difficulties. Nevertheless, these shortcomings did not have a significant impact on the results of the study.

\section{Conclusion}

The speech of the respondents is characterized by a high degree of similarity with the Russian literary language, and demonstrates features of closely related Ukrainian. These features are most clearly manifested in the phonetic aspect, less explicitly in morphology and syntax, and almost not reflected in the lexical system.

The research is sponsored by the government of Sevastopol and Russian Foundation of Fundamental Research (grant number 18-412-920001 "The Russian language functioning in Sevastopol as a projection of social, ethnic and cultural policy in the second half of the $20^{\text {th }}$ - early $21^{\text {st }}$ century: dialectalogical and historical description and mapping").

\section{References}

1. S. A. Myznikov, Russian lexicography of the $21^{\text {st }}$ century: issues and solutions, 93-96 (2016)

2. N. A. Meshcherskii (ed.), Russian dialectology (Vysshaya shkola, Moskva, 1972)

3. E. S. Kashirina, A. A. Novikov, Yu. L. Sit'ko, Geopolitiks and Ekogeodynamics of Regions, 4 (4), 361-368 (2018)

4. V. I. Belikov, ActaPhilologica, 1, 36-52 (2007)

5. E. V. Brysina, R. I. Kudryashova, V. I. Suprun, Izvestia of the Volgograd State Pedagogical University, 3, 3-10 (2005)

6. N. N. Durnovo, N. N. Sokolov, D. N. Ushakov, Dialectological map of the Russian language in Europe with an essay on Russian dialectology (Sinodal'naya tipografiya, Moskva, 1915)

7. R. I. Avanesov, V. G. Orlova (ed.), Russian dialectology (Nauka, Moskva, 1965)

8. L. L. Kasatkin (ed.), Russian dialectology (ASTPress, Moskva, 2013)

9. A. N. Rudyakov (ed.), Georusistics: The Russian language in the global world (Leksrus, Moscow, 2016)

10. L. I. Barannikova, Voprosy Jazykoznanija (Topics in the study of language), 2, 22-82 (1975)

11. N. S. Antonenko, Proceedings of the $36^{\text {th }}$ International Student, Postgraduate and Young Scientists Conference "Lomonosov - 2019", 188-190 (2019)

12. Yu. L. Sit'ko, Bulletin of the Moscow Region State University, 3, 23-31 (2017) 